\title{
A resistente visão aristotélica no ensino de metáforas em gramáticas brasileiras
}

\section{Kaline Girão Jamison}

Universidade da Integração Internacional da Lusofonia Afro-brasileira (UNLAB)

\begin{abstract}
Resumo
$\mathrm{O}$ ensino de língua portuguesa no Brasil baseia-se em regras gramaticais prescritas que, muitas vezes, promove um distanciamento entre a língua e a realidade do aluno. No caso do ensino da metáfora, percebe-se que na maioria das gramáticas, a abordagem de ensino ainda está estagnada numa perspectiva aristotélica, pois trata esse fenômeno apenas como um ornamento linguístico. Contudo, estudos sobre a metáfora (LAKOFF; JOHNSON, 1980) têm avançado nos últimos trinta anos, apresentando uma visão de que as metáforas estão no nosso sistema conceitual. Objetivamos mostrar a perspectiva pela qual fenômeno cognitivo tem sido tratado nos últimos vinte anos, em sete das principais gramáticas adotadas em escolas públicas e privadas de Fortaleza, Ceará. Constatamos que houve avanços na abordagem do ensino sobre a metáfora, porém, a perspectiva ainda está presa a moldes tradicionais, uma perspectiva dicotômica e estática, dividindo a linguagem em denotativa e conotativa.
\end{abstract}

Palavras-chave: Ensino de Português; Metáfora; Gramática.

\begin{abstract}
Portuguese language teaching in Brazil is based on prescriptive grammatical rules that often open a gap between language and the student's reality. In the case of metaphor teaching, it can be noticed that in most Portuguese grammars the teaching approach still seems to have stagnated in an Aristotelian perspective, which sees this phenomenon only as a linguistic ornament. However, studies about metaphor (LAKOFF; JOHNSON, 1980) have advanced in the last thirty years, with a new vision that metaphors are in our conceptual system. The goal of our paper is to show the perspective from which this cognitive phenomenon has been handled in the last twenty years, in seven Portuguese grammar books, currently adopted in public and private schools in Fortaleza, Ceará. We found that progress has been made concerning the teaching approach of metaphors; however, the outlook is still trapped in traditional approaches, in a static dichotomous perspective, that divides the language into denotative and connotative.
\end{abstract}

Keywords: Portuguese teaching; Metaphor; Grammar.

\section{INTRODUÇÃO}

O ensino da língua materna no ensino fundamental e médio nas escolas brasileiras baseia-se principalmente no modelo de gramática prescritiva, a partir de regras de gramática normativa. Para Travaglia (2003), a gramática que se ensina na escola provêm de uma visão reducionista e distorcida ou mesmo preconceituosa do que seja 
a gramática da língua. E isso pode criar uma barreira entre a língua e o cotidiano dos alunos, transformando assim, a língua em algo artificial e desconectado.

No tocante ao ensino de figuras de linguagem, percebe-se que o tratamento dado às metáforas ainda segue a tradição de natureza retórica, como se fosse um desvio da norma culta, com função de ornamentação linguística. De fato, ao lermos textos literários, como romance, poesias, crônicas e contos, deparamo-nos com uma linguagem diferente, conotativa e que não descreve a realidade de maneira literal, mas metaforicamente. São inúmeras as passagens em que se autores utilizam a linguagem figurada para compor textos e expressar sentimentos. Camões, por exemplo, ao definir o amor como "fogo que arde sem se ver", procurou ilustrar a relação existente entre o sentimento amor e o fogo para demonstrar semelhanças conceituais, relacionando o amor a calor, à paixão, à excitação, a fervor etc.

Nesse sentido, ao aprenderem, de forma errônea, que o uso da metáfora é restrito à linguagem literária, os alunos tendem a se afastar de seu uso, por entenderem que só precisarão desse recurso linguístico se quiserem embelezar seus textos. Ao atribuirem à metáfora um status de ferramental ornamental literária, eles nem se quer percebem que fazem uso dela, principalmente de modo inconsciente, em situações banais do cotidiano. Assim ao concebermos a metáfora como um elemento não apenas linguístico, mas também como um recurso cognitivo, afastamos dela a ideia de uma função apenas artístico-literária.

Sabemos, porém, que não são apenas os escritores e poetas que usam a metáfora para enriquecer suas falas e escritas com esse poderoso recurso retórico, mas também políticos, escritores, advogados, jornalistas, entre outros. Entretanto, para além da função de adorno estético, o uso dessa figura de linguagem ocorre também em nossas conversas cotidianas, como mencionamos há pouco, quando dizemos, por exemplo, que o preço da gasolina "subiu", ou, quando nos deparamos, no discurso científico, com expressões do tipo: "células-mãe”, para definir células geradoras. Essas recorrências comprovam a existência e a necessidade de uso da metáfora para além do universo literário. O uso da metáfora, portanto, serve para expressarmos um rico conteúdo de ideias que nascem a partir de nosso modo de entender o mundo. Ou seja, o lócus da metáfora não é a linguagem, conforme afirma a maioria das gramáticas, mas o pensamento (LAKOFF, 1987). 
A partir desse posicionamento, portanto, interessa-nos responder à seguinte questão: como sete das principais gramáticas de língua portuguesa, adotadas em escolas públicas e privadas da cidade de Fortaleza, abordam o ensino da metáfora?

\section{PRESSUPOSTOS TEÓRICOS}

Para iniciarmos essa discussão, partimos de um breve panorama sobre a abordagem cognitiva do estudo de tropos figurados: a Teoria da Metáfora Conceitual (LAKOFF; JOHNSON, 1980), a qual nos serve como base para averiguar a forma como as gramáticas abordam esse fenômeno linguístico.

\section{A metáfora segundo a Teoria da Metáfora Conceitual (TMC)}

A concepção de metáfora como intrínseca e como constituinte de nossa forma de pensar veio à tona a partir da publicação, em 1980, de Metaphors we live by pelo linguista George Lakoff e pelo filósofo Mark Johnson. Segundo eles, algumas conceitualizações são metaforicamente estruturadas em nossas mentes e a metáfora consiste em uma operação mental básica pela qual nós entendemos o mundo, ao fazermos mapeamentos entre domínios conhecidos e desconhecidos.

Por exemplo, para que entendamos o conceito abstrato AMOR, por exemplo, precisamos recorrer a outro conceito mais real, já vivenciado por nós, como VIAGEM. Assim, mapeamos esses domínios e formamos a metáfora conceitual O AMOR É UMA VIAGEM (LAKOFF; JOHNSON, 1980) da qual surgem inúmeras outras expressões metafóricas, como: "nosso amor chegou ao fim", "seguimos caminhos separados", "olhamos juntos na mesma direção" etc. É claro que a teoria da metáfora conceitual, doravante TMC, proposta por Lakoff e Johnson (1980) não prevê verdades absolutas, visto que as metáforas também são oriundas do meio cultural e resultam, portanto de mapeamentos relevantes a cada ideologia, de modos de ver o mundo, e das crenças dessas civilizações. Ou seja, por serem convencionais e portanto inconscientes, não poderíamos criar essas metáforas conceituais, como, por exemplo, "o amor é uma árvore", pois não temos controle sobre o modo como fazemos essa representação mental.

Do ponto de vista da TCM, a qual corroboramos, a metáfora é cognitiva, existe na mente e atua no nosso pensamento, independentemente se somos ou não poetas. O fato é que, diferentemente da visão objetivista de metáfora que a concebe como um 
desvio ou ornamentação linguística, não fazemos esforço para produzir e nem para entender certas expressões metafóricas, visto que as metáforas conceituais, quase sempre compartilhadas por membros da mesma sociedade, gerariam essas expressões secundárias. Para Lakoff e Johnson (1980), o que torna essa metáfora conceitual, ao invés de meramente linguística, é a ideia de que sua motivação reside no nível do domínio conceitual.

Lakoff e Johnson (1980) definem três tipos de metáforas conceituais:

- As metáforas orientacionais, que se baseiam na noção de orientação espacial do nosso corpo, tais como, DENTRO-FORA, EM CIMAEMBAIXO, CENTRAL-PERIFÉRICO etc. Tais orientações espaciais são fundadas na noção de corporificação e têm relação com a posição que ocupamos no espaço, que influenciam os conceitos em perspectiva espacial como: FELIZ É PARA CIMA, TRISTE É PARA BAIXO, MENOS É PARA BAIXO, MAIS É PARA CIMA. Diversas expressões podem ser geradas a partir desses mapeamentos: "ela ficou pra baixo quando soube que não havia sido aprovada" etc;

- As metáforas ontológicas são oriundas de nossa experiência com objetos e substâncias físicas e "implicam em projetar características de entidade ou substância sobre algo que não tem essas características de maneira inerente" (LAKOFF, 1987, p. 51). Em “a violência precisa ser destruída”, por exemplo, a metáfora ontológica subjacente VIOLÊNCIA É UMA COISA é identificada. Já na expressão: "acabemos com a violência antes que ela acabe conosco", subjaz a metáfora VIOLÊNCIA É UM SER ANIMADO.

- As metáforas estruturais, segundo Lakoff e Johnson (1980 p. 61), "são baseadas em correlações sistemáticas de nossas experiências". Essa classe de metáforas, segundo os autores, é utilizada quando queremos estruturar ou conceitualizar uma experiência em termos de outra, que compreendemos muito bem. Um exemplo dado pelos autores é a metáfora conceitual: DISCUSSÃO É GUERRA, cujo domínio fonte, GUERRA, serve de base para conceitualizar o domínio alvo DISCUSSÃO. Lakoff e Johnson (1980) explicam que assim como os animas lutam em busca de alimento, abrigo, acasalamento, território etc., nós, animais racionais, usamos técnicas mais sofisticadas, como a guerra, por exemplo, para lutarmos e brigarmos pelo que queremos. No entanto, apesar de usarmos, na maioria das vezes, a disputa verbal 
para derrotarmos nossos oponentes e conquistarmos nossos objetivos, nos apoiamos na experiência de enfrentamento físico para dar sentido a uma discussão verbal. Assim, surgem expressões como: "ele me derrubou com seus argumentos", "meu pai sempre vence em suas discussões" etc.

Por outro lado, conforme a discussão de psicólogos cognitivos, diversos mapeamentos que são gerados entre os domínios fonte e alvo são considerados parciais, visto que nem todos os elementos do domínio fonte conseguem ser mapeados no domínio alvo. No caso do exemplo de AMOR É UMA VIAGEM, alguns aspectos do conceito viagem não se relacionam tão claramente ao conceito amor, como, por exemplo; hospedagem, alimentação, passeios etc. Ou seja, há aspectos que não são mapeados.

Isso foi um ponto de muitas críticas à teoria da metáfora conceitual e Grady (1997) aprofunda-se nessa questão para tentar entender porque o mapeamento não era completo. Além disso, percebeu-se que várias metáforas conceituais não sugeriam correlações diretas com experiências corpóreas, como é o caso da metáfora conceitual TEORIAS SÃO EDIFÍCIOS. Ao contrário da metáfora MAIS É PARA CIMA, em que a experiência nos revela que a medida que empilhamos objetos ou aumentamos o nível de algum líquido em um recipiente o nível da pilha ou do líquido sobe, em TEORIAS SÃO EDIFÍCIOS não se pode afirmar quais as experiências de base corpórea que dão base a essa metáfora.

Ante o exposto, entendemos que diferentemente da tradição aristotélica, que concebia a metáfora como um artifício poético e uma ornamentação linguística, a nova visão de metáfora não limita seus domínios apenas ao uso linguístico, nem arbitrário, mas sim, ao uso cognitivamente motivado, visto que se apresentam em nossos pensamentos e em nos mais diversos discursos. Nessa perspectiva, acreditamos que, ao invés de manter uma abordagem objetivista e tradicional do uso da metáfora, as gramáticas de língua materna deveriam trazer à tona, pelo menos superficialmente, uma demonstração da teoria da metáfora conceitual no tocante ao ensino dessa figura de linguagem, de modo a mostrar aos alunos que a metáfora é reflexo de padrões de pensamentos e de formas de conceitualizar o mundo e que, por isso, pensar metaforicamente não é apenas um privilégio de poetas 


\section{PRESSUPOSTOS METODOLÓGICOS}

Nossa pesquisa é bibliográfico-exploratória e de natureza qualitativa, a qual consiste em um desdobramento de nossa dissertação de Mestrado (JAMISON, 2011), cujo objetivo era pesquisar, sob o viés da Linguística Cognitiva, como a conceitualização de ideias abstratas eram feitas por meio da metáfora e de outros tropos em discursos de mulheres em situação de violência.

Após esse estudo, surgiu a curiosidade de investigar como esse recurso linguístico-cognitivo, capaz de revelar tanto de nosso sistema conceitual e de nossa forma de ntender o mundo, estava sendo ensinado nas escolas de Fortaleza, por meio de uma investigação das gramáticas adotadas.

Dessa forma, nosso intuito consiste em apontar a defasagem que acreditamos existir nas gramáticas do ensino da língua portuguesa, no que diz respeito ao estudo de metáforas. Para isso, escolhemos sete gramáticas de Português, que já estiveram dentre as obras entre as mais utilizadas por estudantes cearenses nos Ensinos Fundamental e Médio. Desse modo, as gramáticas foram escolhidas considerando as mais adotadas por professores que atuam, principalmente, em escolas da rede privada em Fortaleza, Ceará.

Destacamos também que a seleção das obras analisadas foi feita de modo a identificar e elucidar possíveis mudanças e avanços na abordagem do ensino da metáfora nos últimos vinte anos. Por este motivo, optamos começar nossas análises por quatro gramáticas lançadas nos anos noventa (conforme os três primeiros títulos assinalados na tabela abaixo) e outras três publicadas na primeira década dos anos 2000. Desse modo, o corpus se constitui dos seguintes títulos:

Tabela 1: Gramáticas de língua portuguesa pesquisadas.

\begin{tabular}{|l|l|l|l|l|}
\hline \multicolumn{1}{|c|}{ Gramática } & $\underline{\text { Autor (es) }}$ & $\underline{\text { Publicação }}$ & $\underline{\text { Edição }}$ & $\underline{\text { Editora }}$ \\
\hline $\begin{array}{l}\text { 1. Aprender e Praticar Gra- } \\
\text { mática }\end{array}$ & Mauro Ferreira & 1992 & $1^{\text {a }}$. & FTD \\
\hline $\begin{array}{l}\text { 2. Gramática Contempo- } \\
\text { rânea da Língua Portuguesa }\end{array}$ & $\begin{array}{l}\text { José de Nicola e } \\
\text { Ulisses Infante }\end{array}$ & 1993 & $11^{\mathrm{a}}$. & Scipione \\
\hline
\end{tabular}




\begin{tabular}{|l|l|l|l|l|}
\hline 3. Gramática Nova & $\begin{array}{l}\text { Emílio Carlos Fara- } \\
\text { co e Francisco Mar- } \\
\text { to de Moura }\end{array}$ & $9^{\mathrm{a}}$. & Ática \\
\hline $\begin{array}{l}\text { 4. Nossa Gramática: teoria e } \\
\text { prática }\end{array}$ & $\begin{array}{l}\text { Luiz Antonio Sac- } \\
\text { coni }\end{array}$ & 1999 & $25^{\mathrm{a}}$. & Atual \\
\hline $\begin{array}{l}\text { 5.Novíssima Gramática da } \\
\text { Língua Portuguesa }\end{array}$ & $\begin{array}{l}\text { Domingos Paschoal } \\
\text { Cegalla }\end{array}$ & 2005 & $46^{\mathrm{a}}$. & $\begin{array}{l}\text { Companhia } \\
\text { Editora Na- } \\
\text { cional }\end{array}$ \\
\hline $\begin{array}{l}\text { 6. Moderna Gramática por- } \\
\text { tuguesa }\end{array}$ & $\begin{array}{l}\text { Evanildo Bechara } \\
\text { 7. Português, Literatura, } \\
\text { Gramática e Produção de } \\
\text { Texto }\end{array}$ & $\begin{array}{l}\text { Leila Laura Sar- } \\
\text { mento e Douglas } \\
\text { Tufano }\end{array}$ & $37^{\mathrm{a}}$. & $\begin{array}{l}\text { Nova Fron- } \\
\text { teira }\end{array}$ \\
\hline
\end{tabular}

Fonte: elaborado pela autora.

As análises seguiram um ordem cronológica crescente de publicação e foram realizadas a partir, a princípio, da análise do sumário das obras, com vistas a identificar o modo como o estudo sobre a metáfora era inserido em termos de classe gramatical e suas respectivas categorizações . Em seguida, buscamos descrever como esse tropo linguístico era definido e exemplificado em cada obra.

\section{ANÁLISE E DISCUSSÃO DOS DADOS}

Nesta seção, trazemos as sete gramáticas de língua portuguesa a serem analisadas.

\section{"Aprender e Praticar Gramática" (FERREIRA 1992)}

No sumário dessa obra, Ferreira (1992) insere a metáfora na última unidade, a trigésima segunda, intitulada "Linguagem Figurada". E dentro do subgrupo "Principais Figuras de Linguagem", logo no sumário, a página numerada referente à metáfora e às outras figuras de linguagem podem ser visualizadas.

$\mathrm{Na}$ introdução da trigésima segunda unidade, Ferreira (1992, p. 434) explica que as figuras de linguagem 
nascem da intenção ou da necessidade do falante (ou escritor) de dizer as coisas de uma maneira nova, diferente e criativa. O que se pretende, quando se usa a linguagem figurada é fazer com que o ouvinte (ou leitor) se surpreenda, sensibiliza-se e, assim, fique mais atento ao que está sendo falado (ou escrito).

Como visto, a própria inserção da metáfora como uma figura de linguagem já a enquadra no modelo tradicional, que a caracteriza como um fenômeno puramente de ordem linguística, quando na verdade, ela pode também se manifestar em imagens. Observa-se, no entanto, que o autor chama a atenção para o fato de que a utilização da linguagem figurada não é "um privilégio dos grandes escritores" (1992: 434) e que todos fazem uso dela. Porém, o autor, paradoxalmente, explica que a importância de conhecer as figuras de linguagem deve-se ao fato de que tal conhecimento ajudaria em uma melhor compreensão da beleza dessa linguagem nos textos literários. Facilmente percebemos que a visão do autor é muito limitada em relação a este fenômeno linguístico. Definindo o uso da metáfora apenas no âmbito literário e provocando em nós o seguinte questionamento: esse recurso linguístico (segundo sua própria definição) é ou não é de uso comum?

Consoante essa abordagem, Ferreira (1992, p. 436) classifica a metáfora como um "recurso poético" (p. 436) e a define como "[...] a mudança do sentido comum de uma palavra por outro sentido possível que, a partir de uma comparação subentendida, tal palavra possa sugerir". Observamos, inclusive, que o autor utiliza versos de Manuel Bandeira para explicar a "associação de ideias" (p. 436) que ocorre nesse fenômeno.

\section{"Gramática Contemporânea da Língua Portuguesa" (NICOLA; INFANTE, 1993)}

Assim como a gramática anterior, a Gramática Contemporânea da Língua Portuguesa também traz em seu sumário a metáfora dentro do último capítulo, na seção de "Figuras de Linguagem". Contudo, ao contrário da gramática de Ferreira (1992), que exibe em seu sumário a numeração de todas a figuras de linguagem, dentre elas, a metáfora, essa gramática não as enumera. Os autores deram preferência à criação de três subdivisões: "Denotação e Conotação"; "Classificação das figuras" e "Exercícios e Testes".

$\mathrm{Na}$ introdução desse capítulo, os atores tratam sobre os sentidos que as palavras podem ter nas sentenças "dependendo de sua colocação numa determinada frase" (NICOLA; INFANTE, 1993, p. 431). Ou seja, de forma bem reducionista, eles deli- 
mitam os sentidos que uma palavra pode expressar como: figurado ou literal, como se a fronteira entre eles fosse inequívoca. Nesse afã, explicam que é esperado que a palavra apresente variações em seus significados, podendo estar no I) sentido denotativo: "sentido original, impessoal e indiferente do contexto, tal como aparece no dicionário" (p. 432) ou II) sentido conotativo: quando a palavra aparece com "significado alterado, passível de interpretações diferentes” (p. 432).

É interessante observar que ao final dessa introdução, mesmo atribuindo o uso da conotação à linguagem poética, os autores admitem que o sentido conotativo também é comum em nossa linguagem cotidiana, mas que surge em consequência "da forte carga de afetividade e expressividade". Assim, deixa transparecer que correlaciona o uso da linguagem figurada a um esforço intencional e poético.

Nicola e Infante (1993), dividem as figuras de linguagem em três subgrupos de figuras: de construção, de pensamento e de palavra. Interessante notar que a Metáfora foi introduzida no terceiro grupo, o de "Figuras de palavra", que segundo os autores, "consiste na substituição de uma palavra por outra, isto é, no emprego figurado simbólico, de uma palavra por outra quer por relação muito próxima, (contiguidade), quer por uma associação, uma similaridade". E assim, introduz as figuras "metáfora" e "metonímia". Ao definir o que é metáfora, os autores Nicola e Infante (1993, p.442) citam Mattoso Câmara e atentam para o fato de que a metáfora "vai além de uma mera comparação", pois é a (...) transferência de um termo para um âmbito de significação que não é o seu. Não há, aparentemente, uma relação real entre as duas palavras, isto é, 'não se fundamenta numa relação objetiva, mas sim, numa relação toda subjetiva.

Desse modo, a metáfora, que é colocada no âmbito da subjetividade, também é tratada tão somente como um recurso estilístico e linguístico, como já se percebe na própria categoria na qual é inserida: a de "figura de palavra".

O curioso é perceber que na subdivisão "figuras de pensamento", onde supostamente a metáfora deveria estar inserida, os autores não caracterizam essa subdivisão e nem explicam quais as características em comum entre os elementos lá listados (antítese, eufemismo, hipérbole, ironia apóstrofe, gradação e prosopopéia).

\section{"Gramática Nova" (FARACO ;MOURA, 1995)}


Essa obra também traz no sumário a metáfora inserida no último capítulo, dentro de "Figuras de Linguagem", contendo uma subcategoria "Principais Figuras de Linguagem", na qual a metáfora aparece numerada.

$\mathrm{Na}$ introdução desse capítulo, os autores mostram duas imagens diferentes de Marilyn Monroe para demonstrar a função das figuras de linguagem. A primeira, na qual a atriz é retratada em preto e branco, é considerada menos expressiva do que a segunda, na qual cores vibrantes ressaltam a maquiagem e os cabelos loiros de Marylin. Assim, Faraco e Moura (1995) mostram que a mensagem da segunda foto "é muito mais expressiva, desperta mais atenção do observador" (FARACO; MOURA, 1995, p. 304).

Em seguida, fornece o exemplo "O coração dava-me coices desesperados...", de Graciliano Ramos, para demonstrar que a língua, além de sua "finalidade prática (FARACO; MOURA, 1995, p. 304), pode servir para tornar uma "mensagem mais expressiva". E confirmam: "figura de linguagem é o recurso utilizado para realçar uma ideia." (FARACO; MOURA, 1995, p. 304).

Isso posto, logo na introdução, fica claro que a metáfora também é mostrada como um ornamento, usada com a finalidade de realçar a expressividade da mensagem. Mais uma vez, observa-se que a metáfora era mesmo entendida como um recurso linguístico usada de forma consciente.

Na subcategoria "Principais Figuras de Linguagem”, a Metáfora aparece logo após a "Comparação", sendo definida como "a mais importante das figuras de linguagem" (FARACO; MOURA, 1995, p. 306). Contudo, as definições dadas a essa figura não justificam sua importância: "a metáfora é parecida com a comparação", ou ainda, “(...) é uma transferência de significado que se dá entre duas coisas” (p.306). Depois, subdividem-na em dois tipos: as que os dois termos aparecem na frase ("minha mãe é um papagaio") e as que apenas um termo é percebido ("não encontro a chave de mim").

\section{"Nossa Gramática: teoria e prática" (SACCONI, 1999)}

A quarta gramática que analisamos, se comparadas às demais, já apresenta algumas diferenças em relação à apresentação da metáfora no sumário. Enquanto as outras a trazem no último capítulo, nessa, ela aparece no vigésimo nono capítulo dos trinta e quatro existentes. Também, o autor a posiciona dentro da categoria Semântica, o que representa uma mudança, pelo menos aparentemente, significativa. Em oposi- 
ção às outras, que inseriam, de forma não explícita, a Metáfora no âmbito da Estilística, Sacconi (1999) dá um passo a frente, visto que propõe no sumário enxergar a metáfora sob a ótica do significado e não apenas da forma e da expressividade.

Por outro lado, ainda no sumário, o autor subdivide o capítulo em Linguagem Figurada e Figuras de Linguagem, as quais são ainda subclassificadas em "Figuras de Palavras" (onde a metáfora está inserida), Figuras de Sintaxe e Figuras de Pensamento, assim como as gramáticas anteriores. Como vemos, nesse aspecto, não há diferença em relação às outras gramáticas até agora analisadas.

$\mathrm{Na}$ introdução do capítulo, o autor faz uma definição, no mínimo sucinta, do que seja Linguagem Figurada: "é usada fora dos padrões normais (grifo nosso) da comunicação, com o emprego das figuras de linguagem" (SACCONI, 1999, p. 492). Tomado por uma visão tradicionalista, normativa e reducionista, Sacconi (1999) demarca as figuras de linguagem como "desvios das normas estritas de linguagem, com os fins expressivos" (SACCONI, 1999, p. 492).

Aqui, a metáfora é posta na categoria Tropos e definida como "o emprego de palavra fora de seu sentido normal (grifo nosso), por efeito de analogia (comparação)" (SACCONI, 1999, p. 492). Ora, na própria definição do autor, percebe-se que a ideia de SENTIDO NORMAL é entendida como uma caixa, um recipiente, visto que ele usa o advérbio "fora" para se referir ao que não faz parte da "normalidade". Temos aí uma metáfora que passou desapercebida pelo próprio autor. Quer dizer que sua definição de metáfora não está dentro dos "padrões normais da comunicação"?

Além de tratar a metáfora como um emprego linguístico "anormal", visto estar fora do sentido normal, o autor a subcategoriza em: metáforas ou puras. As impuras (note que se trata de uma expressão metafórica, pois não há impureza em uma figura de linguagem) acontecem quando estão presentes os dois termos da comparação; “A Amazônia é o pulmão do mundo" (SACCONI, 1999, p. 492) e as puras, quando não está presente nenhum (grifo nosso) termo da comparação; "Na sua mente povoa só a maldade". Consideramos essa classificação confusa e contraditória, pois, segundo o grifo do autor, percebemos sim a presença de um termo metafórico nessa oração: "povoa", visto que a "maldade" não é feita de habitantes. Além disso, Sacconi (1999) deixa de indicar o termo "maldade" também é empregado de maneira metafórica, pois se trata de um traço psicológico não que está fisicamente na mente de ninguém. Assim, com essas lacunas, percebe-se que o conceito e o uso desse tropo não consegue 
ser examinado de maneira mais profunda, talvez porque os estudos sobre metáforas ainda não estivessem disponíveis aos gramáticos brasileiros na década de noventa.

\section{"Novíssima Gramática da Língua Portuguesa"(CEGALLA, 2005)}

A gramática de Cegalla (2005), assim como todas as outras até aqui examinadas, apresenta a Metáfora dentro de Figuras de Linguagem, também subposicionada na seção Figuras de Palavras. Ao contrário da gramática de Sacconi (1999), que a insere na categoria de Semântica, aqui ela é proposta dentro do segmento de Estilística.

De forma objetiva, o autor descreve figuras de linguagem como "figuras de estilo" e as define como "recursos especiais de que se vale quem fala ou escreve, para comunicar à expressão mais força e colorido, intensidade e beleza" (CEGALLA, 2005 , p. 614) e as classificam também em três tipos: de palavras, de construção e de pensamento.

No que tange à metáfora, do mesmo modo é atribuída a ela uma conotação de "desvio de significação que usamos quando quisemos atingir um "efeito expressivo" (CEGALLA, 2005, p. 614). Também descrita como: “o desvio da significação própria de uma palavra, nascido de uma comparação mental ou característica comum entre dois seres ou fatos". Mais uma vez, observamos que há uma incongruência na definição do autor quando a define como "desvio", porém, ao mesmo tempo, assegura que esse é "próprio" de uma palavra. Em outros termos, propomos que se a metáfora refere-se a um fenômeno que se "desvia" e "foge" dos parâmetros "normais" da significação da palavra, há uma distorção que não pode ser própria a ela, como o próprio nome sugere.

De qualquer forma, percebemos que há um avanço na definição de metáfora na medida em que é conferida a ela um caráter mental, o que sugere uma aproximação à ideia de que a metáfora não se atrela apenas a propósitos estéticos, mas que também está vinculada a nossa necessidade de compreender o mundo e a usamos sem esforço, pois faz parte do pensamento humano (KÖVECSES, 2010).

Outro aspecto interessante nessa gramática é que o autor ilustrou essa relação de semelhança entre dois "seres ou fatos" (KÖVECSES, 2010), por meio de conjuntos de intersecção, exibindo que a relação de semelhança ocorre devido ao cruzamento das características dos dois conjuntos A e B, formando o subconjunto das semelhanças C. 
Por fim, a metáfora é tratada como "a mais importante e frequente figura de estilo (grifo nosso)" (KÖVECSES, 2010, p.614), dado o seu caráter "enfático, incisivo e direto". Vale destacar que, muito embora tenha havido um progresso quanto a percepção de metáfora quanto simplesmente a uma figura de ordem linguística, pois foi o único gramático que a tratou sob o ponto de vista mental, ainda é adotado o ponto de vista de que ela serve apenas como ornamentação, como embelezamento retórico e usada deliberadamente para efeitos estéticos.

\section{"Moderna Gramática Portuguesa" (BECHARA, 2009)}

Outro ponto de visto digno de nota é o do gramático Evanildo Bechara (2009). Diferentemente das outras analisadas até agora, nessa obra, o autor não apresenta a categoria Linguagem Figurada em seu sumário, o que dificulta na identificação da metáfora no sumário, visto que parece não haver uma concordância entre os gramáticos sobre a parte onde ela deva ser inserida.

Finalmente, encontramos a metáfora nessa gramática em duas partes distintas: no capítulo vinte e três, intitulado "Lexemática" (BECHARA, 2009, p. 543), inserida na parte "Estruturas das Unidades" (BECHARA, 2009, p.498) e também no capítulo vinte e nove "Noções elementares de Estilística", parte da subdivisão chamada "Para além da Gramática” (p.668).

Segundo Coseriu (1968 apud LÓPEZ, 2014), a Lexemática trata do estudo da significação lexical e das relações de significação do léxico. Nessa perspectiva, o autor define a metáfora como uma das causas de alteração semântica do léxico: "mudança de significado motivada pelo emprego em solidariedades, em que os termos implicados pertencem a classes diferentes, mas pela combinação se pertencem também como assimilados" (BECHARA, 2009, p.547).

Interessante notar que o autor distingue metáfora linguística daquela motivada extra linguisticamente. Segundo Huang (2005), essa distinção já pode ser considerada um avanço para "além do nível da palavra na concepção da metáfora" (p.18). Ainda assim, a concepção de metáfora adotada por Bechara (2009), na primeira parte dessa gramática dita "escolar", mostra-se enraizada em uma abordagem tradicional, parecendo distanciar o aluno da compreensão desse fenômeno, por a metáfora ser tratada de forma técnica e dissociada da linguagem cotidiana.

Em outro momento, na mesma obra, como já mencionado, o gramático também trata brevemente sobre a metáfora. No capítulo "Noções elementares de Estilísti- 
ca", ele insere o estudo da metáfora dentro do subcampo "Estilística Semântica", que pesquisa "a significação ocasional e expressiva de certas palavras" (p. 782) nas figuras de linguagem, como a metáfora.

Até então, esse subcampo da Estilística, a Semântica, ainda não havia sequer sido mencionado nas outras gramáticas aqui analisadas. Nesse ponto, portanto, percebe-se um avanço, visto que há uma aproximação da expressividade com a significação. Sobre isso, Cherubim (1989) já apontava a possibilidade de estudar no nível do significante a natureza estilística das figuras de linguagem e assegura: "significados inferidos por meio do signo também são problemas da Semântica, inclusive porque, pela sua própria natureza, a língua só existe com a finalidade de produzir significados" (p.150). Em outros termos, mesmo sem perceber e de forma ainda muito tímida, Bechara (2009) transporta o estudo das figuras de linguagem para além do âmbito da expressividade, aproximando-o à própria natureza da linguagem humana (BALLY, 1951 apud CHERUMBIM, 1989), embora não se aprofunde e nem atribua a essa categoria linguística uma posição cognitiva.

"Português, Literatura, Gramática e Produção de Texto" (SARMENTO; TUFANO, 2010)

Dentre as gramáticas analisadas, essa, de edição mais recente, nada difere das mais antigas no modo de apresentação da metáfora no sumário. Percebemos haver um capítulo intitulado "Linguagem, Linguística e Semântica", no qual, em princípio pensávamos encontrar a metáfora. Contudo, era no capítulo seguinte, "Figuras de Linguagem", e à subcategoria "Figuras de palavras ou tropos" que a metáfora viria vinculada.

Embora tenha sido apresentada pela primeira vez no mesmo capítulo a junção entre os estudos de Estilística e Semântica, demonstrando um avanço, as figuras de linguagem foram deixadas fora do domínio do sentido e expressividade, pelo menos conforme nos evidencia o sumário.

$\mathrm{Na}$ introdução do capítulo quatorze, onde está sendo tratada a metáfora, os autores apresentam um poema para demonstrar que a figura de linguagem é um "recurso de expressão que consiste no emprego da linguagem em um contexto inesperado, seja no que diz respeito ao sentido, à posição ou à combinação de palavras" (SARMENTO; TUFANO, 2010, p.257). Em seguida, as figuras de palavras são tipificadas e de- 
finidas, segundo os autores, como uma "transposição do sentido literal das palavras para o sentido figurado".

Outro fator inovador foi perceber a presença da metáfora visual nessa obra, fato que amplia o ponto de vista que existia sobre metáfora, a de que era um fenômeno vinculado à linguagem verbal. A explicação sobre o que é metáfora é introduzida com a fotografia de um anúncio publicitário, no qual o anunciante faz uma relação entre intestino preso e cadeado.

No entanto, a definição de metáfora como "o emprego de uma palavra (grifo nosso) fora de seu sentido próprio, podendo ter com base uma comparação subentendida, em que o elemento comparativo está implícito, ou ser motivada por nosso conhecimento prévio, além da comparação" (SARMENTO; TUFANO, 2010, p.260), o autor demonstra um paradoxo, pois, conforme destacamos em negrito, os autores ainda se mostram "presos" à concepção de metáfora como um artifício da linguagem verbal, mesmo havendo mostrado um anúncio publicitário que demonstra o contrário.

De qualquer forma, não se percebe na concepção de metáfora adotada por esses gramáticos um vínculo predominante apenas ao campo da expressividade, com vimos anteriormente. Tanto na abordagem, ao mostrar uma metáfora visual, quanto na definição deles, podemos detectar um olhar mais atualizado, embora ainda esteja aquém do que se espera no que diz respeito ao estudo da metáfora enquanto um mecanismo de expressividade cognitivamente motivada.

Como forma de resumirmos as análises aqui realizadas, esboçamos, a seguir, uma tabela identificando as gramáticas e suas respectivas formas de localizar o estudo da metáfora em seus indíces e sumários, assim como as principais definições fornecidas sobre metáforas e sobre figuras de linguagem (categoria que engloba, dentre os tropos, a metáfora).

Tabela 2: Resumo da localização da metáfora nos índices e sumários e das definições apresentadas nas gramáticas de língua portuguesa pesquisadas.

\begin{tabular}{|c|c|c|}
\hline Gramática & $\frac{\frac{\text { Unidade e subtó- }}{\text { pico em que está }}}{\underline{\text { inserida }}}$ & Definição apresentada \\
\hline $\begin{array}{l}\text { 1. Aprender e Praticar Gra- } \\
\text { mática (1992) }\end{array}$ & Linguagem Figurada & $\begin{array}{l}\text { "recuso poético que a promo- } \\
\text { ve a mudança do sentido co- } \\
\text { mum de uma palavra por ou- } \\
\text { tro sentido possível que, a } \\
\text { partir de uma comparação } \\
\text { subentendida, tal palavra pos- }\end{array}$ \\
\hline
\end{tabular}




\begin{tabular}{|c|c|c|}
\hline & & sa sugerir" \\
\hline $\begin{array}{l}\text { 2.Gramática Contemporânea } \\
\text { da Língua Portuguesa (1993) }\end{array}$ & $\begin{array}{l}\text { Figuras de Lingua- } \\
\text { gem } \\
\text { * Figura de Palavra }\end{array}$ & $\begin{array}{l}\text { "consiste na substituição de } \\
\text { uma palavra por outra, isto é, } \\
\text { no emprego figurado simbó- } \\
\text { lico, de uma palavra por outra } \\
\text { quer por relação muito pró- } \\
\text { xima, (contiguidade), quer } \\
\text { por uma associação, uma si- } \\
\text { milaridade" }\end{array}$ \\
\hline 3. Gramática Nova (1995) & $\begin{array}{l}\text { Figuras de Lingua- } \\
\text { gem } \\
\text { *Principais figuras } \\
\text { de linguagem }\end{array}$ & $\begin{array}{l}\text { "a mais importante das figu- } \\
\text { ras de linguagem";"a metáfo- } \\
\text { ra é parecida com a compara- } \\
\text { ção"; "(...) é uma transferên- } \\
\text { cia de significado que se dá } \\
\text { entre duas coisas" }\end{array}$ \\
\hline $\begin{array}{l}\text { 4. Nossa Gramática: teoria e } \\
\text { prática (1999) }\end{array}$ & $\begin{array}{l}\text { Semântica } \\
\text { Figuras de Lingua- } \\
\text { gem }\end{array}$ & $\begin{array}{l}\text { "é usada fora dos padrões } \\
\text { normais da comunicação, } \\
\text { com o emprego das figuras de } \\
\text { linguagem"; "o emprego de } \\
\text { palavra fora de seu sentido } \\
\text { normal, por efeito de analogia } \\
\text { (comparação)" }\end{array}$ \\
\hline $\begin{array}{l}\text { 5.Novíssima Gramática da } \\
\text { Língua Portuguesa (2005) }\end{array}$ & $\begin{array}{l}\text { Eestilística } \\
\text { *Figuras de Lingua- } \\
\text { gem } \\
* * \text { Figura de Palavra }\end{array}$ & $\begin{array}{l}\text { "recursos especiais de que se } \\
\text { vale quem fala ou escreve, } \\
\text { para comunicar à expressão } \\
\text { mais força e colorido, inten- } \\
\text { sidade e beleza"; "desvio de } \\
\text { significação que usamos } \\
\text { quando quisemos atingir um } \\
\text { "efeito expressivo"; "o desvio } \\
\text { da significação própria de } \\
\text { uma palavra, nascido de uma } \\
\text { comparação mental ou carac- } \\
\text { terística comum entre dois } \\
\text { seres ou fatos"; "a mais im- } \\
\text { portante e frequente figura de } \\
\text { estilo". }\end{array}$ \\
\hline $\begin{array}{l}\text { 6. Moderna Gramática portu- } \\
\text { guesa (2009) }\end{array}$ & $\begin{array}{l}\text { Lexemática } \\
\text { *Estruturas das U- } \\
\text { nidades } \\
\text { Noções elementares } \\
\text { de Estilística } \\
\text { *Estilística Semân- }\end{array}$ & $\begin{array}{l}\text { "mudança de significado mo- } \\
\text { tivada pelo emprego em soli- } \\
\text { dariedades, em que os termos } \\
\text { implicados pertencem a clas- } \\
\text { ses diferentes, mas pela com- } \\
\text { binação se pertencem tam- }\end{array}$ \\
\hline
\end{tabular}




\begin{tabular}{|l|l|l|}
\hline & tica & bém como assimilados" \\
\hline $\begin{array}{l}\text { Português, Literatura, } \\
\text { Gramática e Produção de } \\
\text { Texto (2010) }\end{array}$ & $\begin{array}{l}\text { Figuras de Lingua- "recurso de expressão que } \\
\text { gem } \\
\text { *Figuras de palavras } \\
\text { ou tropos }\end{array}$ & $\begin{array}{l}\text { guagem em um contexto i- } \\
\text { nesperado, seja no que diz } \\
\text { respeito ao sentido, à posição } \\
\text { ou à combinação de pala- } \\
\text { vras"; "o emprego de uma } \\
\text { palavra (grifo nosso) fora de } \\
\text { seu sentido próprio, podendo } \\
\text { ter com base uma compara- } \\
\text { ção subentendida, em que o } \\
\text { elemento comparativo está } \\
\text { implícito, ou ser motivada } \\
\text { por nosso conhecimento pré- } \\
\text { vio, além da comparação" }\end{array}$ \\
\hline
\end{tabular}

Fonte: elaborado pela autora.

A primeira questão problemática que observamos na terceira coluna dessa tabela é que há muita oscilação entre os gramáticos no que diz respeito à definição do campo onde deve estar inserido o estudo da metáfora. Em outras palavras, constatamos a falta de precisão conceitual. Essa observação foi feita tanto em gramáticas publicadas nos anos noventa, quanto nas publicações dos últimos dez anos.

Conforme podemos ainda observar pela tabela, todas as gramáticas estudadas trazem o estudo da metáfora em uma seção ligada a figuras de linguagens, exceto na Moderna Gramática portuguesa (BECHARA, 2009), que a trata como um componente não apenas estilístico, mas também semântico, aproximando-a do campo da construção de sentido, embora a explicação seja superficial e de difícil compreensão para um aluno na escola básica.

Além disso, pelas definições de metáfora coletadas em cada um dessas unidades e capítulos, verificamos que, em geral, resiste o conceito de que a metáfora se ancora principalmente no plano da expressividade e de que seu uso não reflete o "normal", uma vez que se apresenta como um "desvio" motivado pelo seu "efeito ornamental". 


\section{CONSIDERAÇÕES FINAIS}

Esse estudo comprovou a necessidade de um olhar mais cuidadoso e preciso sobre a questão do ensino de metáforas e sobre a forma como ela é apresentada em gramáticas da língua portuguesa. Com tantas gramáticas já publicadas ao longo do tempo é inconcebível que haja tanta oscilação em torno de um assunto tão essencial como esse. Observamos que, em algumas gramáticas, a metáfora é apresentada, predominantemente, como um tópico pertencente à Estilística, já em outras, como pertencente à Semântica. Mas, há ainda os casos em que a metáfora aparece "solta", juntamente com outros fenômenos linguísticos e sem aprofundamento adequado.

Outra questão que deve ser destacada diz respeito ao fato de ainda circularem no mercado editorial gramáticas que apregoam a ideia da metáfora como um "desvio linguístico", quase aproximando a ideia da metáfora a um "erro", ou a algo que foge às regras ditadas pela gramática normativa. Considerar a metáfora um desvio é uma demonstração de que os estudos sobre esse tema, desenvolvidos amplamente em todo o mundo nos últimos trinta anos, não têm sido levados em consideração por nossos gramáticos. Com isso, percebemos uma abordagem da metáfora estagnada em uma visão aristotélica, segundo a qual esse tropo é visto apenas como uma ocorrência da linguagem poética.

Sobre esse aspecto, Luft (2008) alerta para o fato de que a gramática não deveria ser inflexível, fixa e de código normativo, pois ela é algo vivo e devendo, portanto, "registrar sua variabilidade e tendências evolutivas das regras gramaticais" (p.22).

Desse modo, assim como Travaglia (2003), partimos de uma proposta de ensino de gramática cujo objetivo é desenvolver a competência comunicativa no aluno de forma produtiva, gerando diversas habilidades linguísticas dentro e fora de sala de aula. Logo, nossa proposta é trabalhar a metáfora de modo que ela seja percebida como um mecanismo mental involuntário (LAKOFF; JOHNSON, 1980), o que acreditamos que promoverá nos alunos considerável interesse nesse tema, possibilitando uma aproximação dos aprendizes à forma natural e espontânea das ocorrências metafóricas, desmistificando, assim, a imagem de que ela é apenas um "desvio", ou um privilégio de eruditos poetas.

\section{REFERÊNCIAS}

BECHARA, E. Moderna Gramática Portuguesa: Atualizada pelo novo acordo or- 
tográfico. $37^{\text {a }}$. Edição. São Paulo: Editora Nova Fronteira e Editora Lucerna, 2009.

CEGAllA, D. P. Novíssima Gramática da Língua Portuguesa. 46. Edição. São Paulo; Companhia Editora Nacional, 2005.

CHERUBIM, S. Estilística Semântica. Semina: Ciências Sociais e Humanas. Vol 10, N.3, 1989 .

FARACO, C.E.; MOURA, F.M. Gramática Nova. 9a. Edição. São Paulo: Editora Ática, 1995.

FERREIRA, M. Aprender e Praticar Gramática. São Paulo: FTD, 1992.

GRADY, J. E. Foundations of Meaning: primary metaphors and primary scenes. Unpublished Phd. Dissertation. University of California. Berkeley, 1997.

HUANG, C. A metáfora no texto científico de medicina : um estudo terminológico da linguagem sobre aids. Dissertação de Mestrado. Universidade Federal do Rio Grande do Sul. Instituto de Letras. Programa de Pós-Graduação em Letras, 2005.

JAMISON, K.G. Quem casa quer casa: a conceitualização e categorização de violência por mulheres vítimas de violência conjugal. 2011. (Mestrado em Linguística). Universidade Estadual do Ceará, Fortaleza, 2011.

KÖVECSES, Z. Metaphor. 2a. Edição. Nova York: Oxford University Press, 2010.

LAKOFF, G.; JOHNSON, M. Metaphors we live by. London: The University of Chicago Press, 1980.

LAKOFF, G. The Contemporary Theory of Metaphor. In: EVANS, V.; BERGEN, B.; ZINKEN, J. (Ed.) The Cognitive Linguistics Reader. London: Equinox, 2007.

LIMA, P L C. Desejar é ter fome: Desejar e novas ideias sobre antigas metáforas conceituais. 1999. 223 f. Tese (Doutorado) - Curso de Linguística, Departamento de IEL, Unicamp, Campinas, 1999.

LUFT, C.P Língua e Liberdade: Por uma nova concepção da língua materna. (Série Fundamentos) 8a ed. São Paulo: Editora Ática, 2008.

NICOLA, J.; INFANTE, U. Gramática Contemporânea da Língua Portuguesa. $11^{\text {a }}$. Ed. São Paulo: Editora Scipione, 1993.

SACCONI, L.A. Nossa Gramática: teoria e prática. 25ª Edição. São Paulo: Editora Atual, 1999.

SARMENTO, L.L; TUFANO, D. Português: literatura, gramática e produção de Texto. $1^{\text {a }}$. Ed. São Paulo: Editora Moderna, 2010.

TRAVAGLIA, L. C. Gramática e Interação: uma proposta para o ensino de gramática.(9 ${ }^{\text {a }}$ Ed) São Paulo: Cortez Editora, 2003. 


\section{A AUTORA}

Kaline Girão Jamison é mestre em Linguística Aplicada pela Universidade Estadual do Ceará (UECE) doutora em Linguística pela Universidade Federal do Ceará (UFC) e está realizando seu estágio pós-doutoral na Universidade de Brasília em Linguística Aplicada. É professora adjunta A da Universidade da Integração Internacional da Lusofonia Afro-brasileira (UNILAB) e coordena o grupo de pesquisa COMPLIC (Uni$\mathrm{lab} / \mathrm{CNPq})$.

Email: giraokaline@gmail.com 